\title{
Key Indicators For Optimising Supply Chain Performance: The Case Of Light Vehicle Manufacturers In South Africa
}

Intaher Marcus Ambe, University of South Africa (UNISA), South Africa

\begin{abstract}
This article investigates key indicators for optimising supply chain performance of light vehicle manufacturers in South Africa. The article is based on a survey conducted among light vehicle manufacturers in South Africa with origins in Asia and Europe. Semi-structured interview questionnaire was used based on purposive sampling technique and the data was analysed using SPSS. The findings revealed that quality, final product delivery reliability and cost were highly rated and the most important indicators for the South African automotive market. Innovation (radical and incremental changes) was the least important among the indicators sampled. The article further revealed that there is a perceived difference on the importance of supply chain indicators between manufacturers of Asian and European origins. Final product delivery reliability and order delivery lead time tended to be more important to European manufacturers compared to Asian manufacturers. The article attests to the fact that competitiveness in cost, quality and product offerings are paramount to automotive manufacturers in today's turbulent environment. It also reveals key competitive criteria used by European and Asian manufacturers based in South Africa. The article contributes to literature on SCM and reveals the way in which vehicle manufacturers in South Africa do business.
\end{abstract}

Keywords: Performance Indicators; Supply Chain Management; Vehicle Manufacturers; South Africa

\section{INTRODUCTION}<smiles>[C]1C=CCCC=C1</smiles>

upply chain performance indicators are key tools for monitoring and improving the supply chain performance to gain competitive advantage (Taylor, 2004, p. 173). According to Wang, Heng and Chau (2007, p. 333), performance indicators support supply chain management (SCM) goals and provides useful information on long-term decisions. It effectively links supply chain partners to achieve breakthrough performance in satisfying end-customer needs and provide feedback regarding customers' needs and the supply chain's capabilities (Wisner, Tan \& Leong, 2008, p. 486). Aramyan, Alfons, Lansink, Van der Vorst and Van Kooten (2007, p. 304) asserted that performance indicators are the criteria with which performances of products, services and production processes are evaluated. Indicators of supply chain performance have an important role to play in setting objectives, evaluating performance, and determining future courses of actions (Lee, Kwon \& Severance, 2007, p. 444).

Using indicators for the measurement of SCM performance creates an understanding of the supply chain's processes, guides collaboration efforts and optimises supply chain excellence (Fawcett, Ellram \& Ogden, 2007, p. 409). As indicated by Gunasekaran and Kobu (2007, p. 2820), "No measures, no improvement," and it is essential to measure the right things at the right time in a supply chain so that timely action can be taken. Therefore, organisations need to monitor and control their operations on a daily basis to get the performance desired from their supply chains. 


\section{RESEARCH PROBLEM AND QUESTIONS}

Despite the importance of performance indicators in enhancing the SCM performance, implementing a well-built supply chain performance indicator is a daunting and challenging task for decision-makers (Chae, 2009, p. 422). According to Folan and Browne (2005), there are several measures discussed in the literature for measuring the performance of an SCM system. However, few of these studies attempt to determine the minimum number of indicators for measuring the performance of a supply chain. In addition, many SCM performance indicators are static and often lag behind the constantly varying contexts in supply chains (Neto \& Pires, 2011, p. 382). There is also little understanding of how to define and categorise supply chain indicators and set up the structure of people's roles and responsibilities within certain companies (Chae, 2009, p. 423). Furthermore, supply chain indicators are sometimes inadequate because they rely on the use of costs as a primary indicator (Neto \& Pires, 2011, p. 382). Supply chain based companies such as Dell, Walmart, Samsung, Toyota, Lenovo, and Gome have used different performance indicators to support and measure their supply chain practices (Cai, Liu, Xiao \& Liu, 2009, p. 512). The Annual Monitoring Report (AMR) contains about forty-five performance indicators and many academic papers also suggest a number of indicators from diverse points of view (Chae, 2009, p. 423).

Over and above these challenges, little research has been done in the South African context on supply chain performance indicators to ascertain which ones are optimal and employed by which companies. This article intends to fill this void by consolidating relevant literature on supply chain performance indicators and determining which indicators are most important in optimising supply chain performance. In this regard, an attempt has been made in this article to determine suitable performance indicators employed by light vehicle manufacturers in South Africa. It sheds light on the indicators critical to the South African automotive market and it is anticipated that the article will generate further interest in the field of supply chain performance especially in the South African automotive industry. Against this background, the purpose of the article is defined by the following research questions:

Research Question 1: What is (are) the most important key supply chain performance indicator(s) in contributing to optimisation of the supply chain performance of local manufacturers of light vehicles in South Africa?

Research Question 2: $\quad$ Are there any differences regarding the implementation of key supply chain performance indicators between manufacturers of different origin (parent) companies?

A supply chain may be poorly designed and managed unless the right indicators are established to support the organisation's practices. Hence, the manner in which supply chain performance indicators are incorporated into supply chain design plays a vital role in determining the effectiveness of the supply chain. This article therefore contributes to literature on SCM and reveals the way in which vehicle manufacturers in South Africa do business. The article also reveals key competitive criteria used by European and Asian manufacturers based in South Africa. This article begins by providing a discussion on the literature review. The next section of the article is the research methodology, followed by results and discussion and lastly, the conclusion.

\section{THEORETICAL BACKGROUND AND RESEARCH HYPOTHESIS}

This section of the article provides the theoretical background and hypothesis. It reviews related literature on supply chain performance management and types of supply chain performance measures.

\section{Supply Chain Performance Management}

SCM is being recognised as the integration of key business processes across the supply chain. The implementation of SCM involves identifying the supply chain members with whom it is critical to link, the processes to be linked with each of these key members, and the type/level of integration that applies to each process link (Lambert, 2006, p. 5). Stavrulaki and Davis (2010, p. 127) assert that SCM processes which cross organisational boundaries can be easily defined, analysed and improved to provide companies with a sustainable competitive advantage by the identification of key performance measures. Performance measurement is the process of quantifying the efficiency and effectiveness of an action by means of a set of metrics (Gunasekaran \& Kobu, 2007, p. 2821). Hence, supply chain performance measurement is multi-dimensional and no one measure will suffice to measure performance (Asadi, 2012, p. 49). 
Measuring supply chain performance can facilitate a greater understanding of the supply chain, positively influence actors' behaviours, and improve its overall performance. There are many indicators of performance that can be deployed in an organisation. However, as alluded to by Folan and Browne (2005), there are a relatively small number of critical dimensions that contribute more than proportionally to success or failure in the market, which they named key performance indicators. Key performance indicators, therefore, should relate to both effectiveness and efficiency of the supply chain and its actors. According to Van der Vorst (2000), a distinction should be made between performance indicators using three main levels: the supply chain level (e.g. product availability, quality, responsiveness, delivery reliability and total supply chain costs); the organisation level (e.g. inventory level, throughput time, responsiveness, delivery reliability and total organisational costs); and the process level (e.g. responsiveness, throughput time, process yield and process costs). Petterson (2009) asserted that in order to improve supply chain efficiency and effectiveness, four main indicators should be used: profit, lead-time performance, delivery promptness and waste elimination.

Wong and Wong (2008, p. 25) indicated that literatures on performance measurements had not viewed the supply chain as a whole entity, therefore, it is difficult to evaluate performance with multiple inputs and outputs to the system. Lambert and Pohlen (2001, p. 1) asserted supply chain metrics are in actualy about internal logistics performance measures that have an internal focus and do not capture how the firms drive value or profitability in the supply chain. Regardless of their qualitative or quantitative nature, it has been suggested that supply chain performance indicators be measured in the form of input-output ratios (Asadi, 2012, p. 49). The use of such simple performance measures are limited in scope and might be inconsistent with the strategic goals of an organisation. In light of the discussion presented above, this article consolidates relevant literature and suggests why it has been difficult in defining and collating what supply chain indicators are. Table 1 presents the challenges of implementing performance measures in SCM.

Table 1: Difficulty in Defining and Collating What Supply Chain Indicators Are

\begin{tabular}{|c|c|}
\hline Difficulty & Description of Difficulty \\
\hline View of SCM & $\begin{array}{l}\text { - } \quad \text { Performance measurements had not viewed supply chain as a whole entity } \\
\text { - } \quad \text { It is difficult to evaluate performance with multiple inputs and outputs to a system }\end{array}$ \\
\hline Focus of Measures & $\begin{array}{l}\text { - Organisation focuses on traditional financial measures despite the need to provide a } \\
\text { balanced approach to performance measurement } \\
\text { - Too much reliance on the use of costs as a primary indicator }\end{array}$ \\
\hline Complexities in Categorisation & $\begin{array}{ll}\text { - } & \text { Complexity of supply chain metrics } \\
\text { - } & \text { Disagreement over an appropriate categorisation }\end{array}$ \\
\hline Lack of a Balanced Approach & $\begin{array}{l}\text { - } \quad \text { Lack of a balanced approach to integrate financial and non-financial measures } \\
\text { - } \quad \text { Lack of a system thinking } \\
\text { - Absence of an approach for developing and designing supply chain performance } \\
\text { measures }\end{array}$ \\
\hline Orientation & $\begin{array}{l}\text { - Measures tend to be historically oriented and not focused on providing a forward- } \\
\text { looking perspective }\end{array}$ \\
\hline Strategic Nature and Alignment & $\begin{array}{l}\text { - Measures do not relate to important strategic, non-financial performance, like } \\
\text { customer service/loyalty and product quality } \\
\text { - } \quad \text { Measures do not directly link to operational effectiveness and efficiency }\end{array}$ \\
\hline
\end{tabular}

\section{Types of Supply Chain Performance Measures/Indicators}

There are several indicators in the literature and in business organisations recommended for use in measuring the performance of an SCM system (Folan \& Browne, 2005). However, few attempts have been made to determine the minimum number or set of indicators needed in order to measure an SCM system's performance with maximum effectiveness and minimum operating cost (Gunasekaran \& Kobu, 2007, p. 2822). Aromyan et al. (2007, p. 305) noted that studies have shown that supply chains lack accurate indicators of performance for comparison, benchmarking and decision-making. Traditionally, companies have tracked performance based on financial accounting principles, which date back to the ancient Egyptians and Phoenicians (Bora, Chiamsiri \& Krairit, 2004, p. 34). The performance-based measures include (Bora et al., 2004, p. 34): the Balanced Scorecard; the SupplyChain Operations Reference (SCOR) model; the Logistics Scoreboard; Activity-Based Costing (ABC) and Economic Value Analysis (EVA). However, the authors noted that the measures are not exhaustive and merely show 
some of the most popular approaches to measure supply chain performance. The Supply-Chain Operations Reference (SCOR) model was developed by the Supply-Chain Council to provide a process-based approach to SCM and assist firms in evaluating the effectiveness of their supply chains. The SCOR model is based on five distinct management processes: plan, source, make, deliver and return. The major performance attributes of the SCOR model are reliability, responsiveness, flexibility, cost and asset (The Supply-Chain Council, 2008).

Many researchers have proposed new performance measures and metrics considering the changes in markets and enterprise environments. Basu (2001) defined performance measures in five categories, namely: external, consumer, value-based competition, network performance and intellectual capital. Stewart (1995) claims that companies that have outperformed their competitors are found to be superior in four key operational areas: (1) delivery performance, (2) flexibility and responsiveness, (3) logistics costs and (4) asset management. Bagchi (1996) defined the metrics of a supply chain in terms of four categories: time, quality, cost, efficiency and diagnostic measure and used these categories to compare the competitiveness of selected companies.

Fitzgerald et al. (1991) suggest that there are two basic types of measures in an organisation relating to competitiveness and financial performance, which focuses on the determinants of the results (quality, flexibility, resource utilisation and innovation). Van Landeghem and Persoons (2001) build a causal model relating the use of best practices to the resulting performance, grouped under four objectives: flexibility, reaction time, quality and cost. Gunesekaran and Kobu (2007) asserted that business and environmental performance measures can be categorised in terms of quality, time, cost, flexibility and innovation. As indicated by Sezen (2008, p. 233), supply chains should be evaluated based on their ability to respond to changes in products, delivery times, volume and mix; hence flexibility. According to Petterson, (2009, p. 24) the three types of performance measures identified as the necessary components of a supply chain performance measurement system are: flexibility, resource and output. In this regard, Table 2 consolidates a list of possible indicators that could be used to enhance the supply chain performance.

Table 2: List of Key Supply Chain Performance Indicators

\begin{tabular}{|c|c|}
\hline Attributes & Key Performance Indicator \\
\hline Quality & $\begin{array}{l}\text { - } \quad \text { Meeting quality performance standards } \\
\text { - } \quad \text { Defect detected per unit produced per unit purchased } \\
\text { - } \quad \text { Quality awards standards } \\
\text { - } \quad \text { Products per unit sold } \\
\text { Fitness of use }\end{array}$ \\
\hline Flexibility & $\begin{array}{l}\text { - Supply chain response time } \\
\text { - } \quad \text { Production flexibility } \\
\end{array}$ \\
\hline Cost & $\begin{array}{l}\text { - } \quad \text { Cost measures within the organisation } \\
\text { - Total supply chain management cost (across the supply chain) }\end{array}$ \\
\hline Supplier Reliability & $\begin{array}{ll}\text { - } & \text { Effectiveness of suppliers } \\
\text { - } & \text { Identification of suppliers } \\
\text { - } & \text { Improve supplier communication } \\
\text { - } & \text { Improved supplier risk management }\end{array}$ \\
\hline Innovation & $\begin{array}{l}\text { - Annual investment in research and development } \\
\text { - Radical and incremental changes }\end{array}$ \\
\hline Responsiveness & - $\quad$ Order fulfilment lead time \\
\hline Order Delivery Lead Time & $\begin{array}{l}\text { - } \quad \text { Fulfilment of orders on time } \\
\text { - } \quad \text { Damage-free delivery } \\
\text { - } \quad \text { Complete delivery as required } \\
\text { - } \text { Delivery meets customers' requirements }\end{array}$ \\
\hline $\begin{array}{l}\text { Final Product Delivery } \\
\text { Reliability }\end{array}$ & $\begin{array}{ll}\text { - } & \text { Delivery performance } \\
\text { - } & \text { Fill rates } \\
\text { - } & \text { Perfect order fulfilment } \\
\end{array}$ \\
\hline Product Variety & $\begin{array}{l}\text { - } \quad \text { Product families processed in one facility } \\
\text { - } \quad \text { Processing cost and flow times } \\
\text { - } \quad \text { Range of products offered } \\
\end{array}$ \\
\hline Asset Management & $\begin{array}{ll} & \text { Cash-to-cash cycle time } \\
\text { - } & \text { Inventory days of supply } \\
\text { - } & \text { Asset turns }\end{array}$ \\
\hline
\end{tabular}


These indicators are now briefly discussed in relation to their role in supply chain competitive advantage:

\section{Quality}

Quality is conformance to requirement or fitness for use. According to Hugo, Badenhorst and Van Biljon (2004, p. 165), managing product quality in the supply chain is the shared responsibility of all participants. Managing quality in the supply chain is the integration of the quality philosophy of the supplier quality system, the internal system of the vantage point firm and the quality the customer expects. Some of the indicators of quality include a formal quality assurance system, continuous improvement, statistical process control, six sigma limits, fail-safe lot traceability and incoming quality assured (Hugo et al., 2004, p. 166). Jacobs, Chase and Aquilano (2009, p. 210) assert that the quality of a specification of a product relates to decisions and actions made relative to the design and quality of conformance to the design. Adherence to the quality of the design and conformance ensure that the product meets customers' objectives. This is often termed "fitness for use" and it entails identifying the dimensions of the product that the customer wants and developing a quality control programme to ensure that the dimensions are met.

\section{Flexibility}

Flexibility in the supply chain is its agility in responding to random changes in the marketplace in order to gain or maintain competitive advantage (Wisner, Tan \& Leong, 2012, p. 451). Flexibility is thus a performance dimension that considers how quickly automotive manufacturers can respond to the unique needs of customers (Jonsson, 2008, p. 89). Flexibility has become particularly valuable in new product development. Some organisations compete by developing new products faster than their competitors. This requires supply chain partners who are flexible and willing to work closely with designers, engineers and marketing personnel (Bozarth \& Handfield, 2006, p. 30). Supply chain response time and production flexibility are two indicators for flexibility (Cohen and Rousell, 2005, p. 208). Supply chain response time measures the number of days it takes a supply chain to respond to marketplace changes without cost penalties (Bowersox, Close \& Cooper, 2010, p. 392).

\section{Costs}

Cost is an important performance supply chain indicator. Supply chain costs include all costs associated with operating the supply chain, including the cost of goods and total supply chain management cost (Bolstorff \& Rosenbaum, 2003, p. 52). Supply chain costs are associated with forecasting, administration, transportation, inventory, manufacturing, customer service and supplier relationship management (Burt, Petcavage \& Pinkerton, 2010, p. 308). Because cost performance is critical, it is tracked more carefully and comprehensively than any other aspect of competitive performance (Fawcett et al., 2007, p. 412). Cost control and cost reduction capabilities must be intrinsic to structure, processes, culture and technology foundation for an organisation to survive and thrive.

\section{Supplier Reliability}

By evaluating supplier performance, organisations hope to identify suppliers with exceptional performance or developmental needs, improve supplier communication, reduce risk and manage the partnership based on the analysis (Wisner et al., 2012, p. 78). According to Wisner et al. (2012, p. 457), reliability of suppliers is one of the most important quality dimensions. Some of the key indicators of supplier reliability include billing accuracy, order accuracy, on-time completion and promises kept.

\section{Innovation}

Innovation in the supply chain ensures that existing technologies, as well as technologies under development, always face the possibility of being pushed aside by alternative developments. In order to assess the technological and market potential of a given technology, its respective car model must be analysed in terms of the key technologies being used, current trends and future innovations. Innovation involves research and development and originates mostly with suppliers. Most innovations begin as optional equipment in new cars. Some of the performance measures and indicators for innovation include the following: annual investment in research and 
development, the percentage of automated processes, the number of new product or service introductions, and the number of process steps required per product (Wisner et al., 2012, p. 514).

\section{Responsiveness}

Supply chain responsiveness refers to how quickly a supply chain delivers products to the customer (Cohen \& Rousell, 2005, p. 208). It involves the time that elapses from a customer's order being received to completed delivery (Jonsson, 2008, p. 88). Order fulfilment lead time is therefore an important measure for supply chain responsiveness and measures the number of days from order receipt in customer service to delivery receipt at the customer's dock (Bolstorff \& Rosenbaum, 2003, p. 51). Taylor (2004, p. 178) mentions that lead time variability should also be considered. Organisations may have short average lead times, but these lead times may vary considerably. In some cases it may be better for organisations to have longer but less variable lead times.

\section{Order Delivery Lead Time}

According to Wisner et al. (2012, p. 517), order delivery lead time encompasses the fulfilment of the average percentage of orders among supply chain members that arrive on time, complete and damage-free, satisfying customer requirements. Order lead time is an important and significant source of competitive advantage for top-performing supply chains and their member companies (Handfield, Monczka \& Giuinipero, 2011, p. 746). The key indicators are due dates, scheduled or promised, and delivery windows. According to Handfield et al. (2011, p. 746), this measure should identify total cycle time and its key components. Measures should focus on reduction through elimination of delays and delivering continuous improvement on target times.

\section{Final Product Delivery Reliability}

Supply chain delivery reliability refers to the performance of the supply chain in delivering the correct product to the correct place at the correct time in the correct condition and packaging in the correct quantity with the correct documentation to the correct customer (Cohen \& Rousell, 2005, p. 208). Reliability generally refers to the ability to deliver products when promised (Wang et al., 2007, p. 149). An organisation can have long lead times, yet still maintain a high level of reliability (Bozarth \& Handfield, 2006, p. 28). Three indicators identified to measure supply Chain delivery reliability are delivery performance, fill rates and perfect order fulfilment. In top-performing supply chains, delivery dates are met $94 \%$ to $100 \%$ of the time. For average organisations, delivery performance is at approximately $70 \%$ to $80 \%$ (Wisner et al., 2012, p. 491).

\section{Product Variety}

According to Wisner et al. (2012b, p. 58), product variety measures the number of product families processed in a facility. Processing costs and flow times are likely to increase with product variety. Owing to the "law of variety" (satisfied customers changing brand because of variety attractiveness), many automotive manufacturers have extended their product range to retain clients, whereas the number of variants per car model grows as well. This affects the complexity of service offers, as well as the complexity of service operations, for example, car maintenance and repair (Godlevskaja, Van Iwaaden \& Van derwiele, 2011, p. 66).

\section{Asset Management}

Supply chain asset management refers to the effectiveness of an organisation in managing assets to support demand satisfaction (Taylor, 2004, p. 184). This includes the management of all assets (Bolstorff \& Rosenbaum, 2003, p. 52). Three indicators that measure supply chain asset management efficiency are cash-to-cash cycle times, inventory days of supply and asset turns. Top organisations have a cash-to-cash cycle time of approximately 30 days (Wisner et al., 2012, p. 490). Inventory days of supply measure the number of days the cash is tied up in inventory. Asset turns are calculated by dividing revenue by total assets, including both working capital and fixed assets (Bolstorff \& Rosenbaum, 2003, p. 52).

Following the discussion on the types of supply chain indicators, it is eminent that an organisation cannot employ all the measures or indicators to optimise its performance. Hence, there are some that are more important 
(key) than others, depending on the organisational goals of the organisation. In this respect, it suffices to say that for an organisation to achieve competitive advantage, key performance indicators must be measured or implemented.

Based on the theoretical background presented, this article hypothesis that:

$\mathbf{H}_{\mathbf{0}}$ : $\quad$ Local manufacturers of light vehicles of Asian and European origin do not differ statistically significantly with regard to their view on the importance of supply chain performance indicators.

$\mathbf{H}_{1}$ : Local manufacturers of light vehicles of Asian and European origin differ statistically significantly with regard to their view on the importance of supply chain performance indicators.

\section{RESEARCH METHODOLOGY}

The article is descriptive and exploratory in nature. Related literature was studied regarding SCM and supply chain performance indicators, which gave rise to the problem, research objectives and the justification for the article. This provided a clear theoretical framework that formed the basis for the article. The outcome of the literature study was the development of a research framework to determine supply chain performance indicators. This served as the focal point for the research framework to be used in the empirical study. The article employed both qualitative and quantitative designs. Triangulation was achieved by using structured interview questions (quantitative), while in some sections the respondents were required to justify their responses (qualitative). The quantitative questions (structured interview) sought to determine the extent to which supply chain indicators were implemented in the South African automotive industry. The research strategy for the study was a survey. A survey is a form of research in which the researcher interacts with respondents to obtain facts, opinion and attitudes (McDaniel \& Gates 2001, p. 30). In survey research, a sample is interviewed in some form or the behaviour of respondents is observed and described in some way (Zikmund, Babbin, Carr \& Griffin, 2010, p. 67). The target population was original equipment manufacturers (OEMs) in the South African automotive industry (local manufacturers). In this article, the total target population was used (all light vehicle manufacturers in South Africa).

In South Africa, major international assemblers and manufacturers have established operations, including OEMs from traditional manufacturing powerhouses in the USA, Japan and Europe, with manufacturers such as Toyota, BMW, Volkswagen, DaimlerChrysler, Nissan, General Motors, Ford (incorporating Mazda, Land Rover and Volvo) and Fiat. Some of the OEMs manufacture certain models locally for the local market and also export some of their production outputs. These automotive manufacturer operations are concentrated in four South African cities: Pretoria, Durban, East London, and Port Elizabeth (Alfaro et al., 2012, p. 15). The South African automotive industry produces two broad categories of vehicles: passenger vehicles and commercial vehicles. Passenger vehicles are classified from A to D class, premium and SUVs, while commercial vehicles are categorised into light commercial, medium commercial and heavy commercial. Passenger vehicle and light commercial vehicles are termed light vehicles. Table 3 presents the various models of passenger and light commercial vehicles assembled in South Africa.

Table 3: Light Vehicle Manufacturers and Local Manufactured Models in South Africa, 2011

\begin{tabular}{|l|c|c|c|}
\hline \multicolumn{2}{|c|}{ Passenger Vehicles (2011) } & Lanufacturers & Models \\
\hline \multicolumn{1}{|c|}{ Manufacturer } & Models & Nissan & Hardbody, NP300, NP200 \\
\hline BMW & 3-series, 4-door & Toyota & Hilux \\
\hline Mercedes-Benz & C-Class, 4-door & Ford & Bantan and Ranger \\
\hline Nissan & Tiida, Livina/Grand Livina & General Motors & Chev Utility and Isuzu KB \\
\hline Toyota & Corolla 4-door and Fortuner & Mercedes-Benz & Mitsubishi Triton \\
\hline Ford & Icon and Focus &
\end{tabular}

Source: AIEC (2012)

Table 4 classifies the vehicle manufacturers in South Africa according to their parent company.

Table 4: Classification of Light Vehicle Manufacturers According to Parent Companies

\begin{tabular}{|l|c|}
\hline \multicolumn{1}{|c|}{ Light Vehicle Manufacturers } & Location Of Parent Company \\
\hline Toyota, Nissan & Asia \\
\hline General Motors & America \\
\hline Mercedes-Benz, BMW and Volkswagen & Europe \\
\hline
\end{tabular}

Copyright by author(s); CC-BY 
A purposive sampling technique was used to determine who the respondents would be. The intention of using purposive sampling was to focus on those who have expert knowledge about supply chain practices and operations (senior supply chain managers). Specific participants for interviews were thus selected according to their strategic positions in the supply chain. Both primary and secondary sources of information were used. Primary data sources were collected through face-to-face interviews (empirical study), while secondary data sources were collected through extensive literature reviews (literature study). The interview questions were semi-structured and measured using a five-point Likert response format with the end points (1) "strongly disagree" and (5) "strongly agree", and (1) "no extent" and (5) "a very great extent". A model (production line) was chosen for each manufacturer on which the interview was based. A total of $12(\mathrm{~N}=12)$ in-depth interviews were conducted for six different models. The data were analysed descriptively using the Statistical Package for Social Sciences (SPSS). The Mann-Whitney $U$ test was conducted to determine the importance of the performance indicators of the different parent companies' origins. The open-ended responses were used to give more meaning to the respondents' views on questions where they were applicable (Gray, Williamson, Karp \& Darphin, 2007, p. 44).

\section{RESULTS AND DISCUSSION}

The results and discussion of the article is presented in relation to the research questions.

Research Question 1: What is (are) the most important key supply chain performance indicator(s) in contributing to optimisation of the supply chain performance of local manufacturers of light vehicles in South Africa?

This research question deals with the respondents' views on the importance of key supply chain performance indicators that contribute to optimising their supply chain performance. Ten key performance indicators in SCM were listed (taken from the literature review), and the respondents were asked to rate the importance of each of the key indicators with a value between 0, indicating not important, and 100, indicating critically important. The question was semi-structured, and the open-ended section required respondents to state the key reasons for their rating. Table 5 shows the rating of the key supply chain performance indicators in order from the highest to the lowest average importance presented in mean and median values.

Table 5: Response Regarding Supply Chain Performance Indicators

\begin{tabular}{|c|c|c|c|}
\hline Supply Chain Indicators & $\mathbf{N}$ & Mean & Median \\
\hline Quality (meeting quality standards of the vehicle) & 12 & 90.83 & 92.50 \\
\hline Final product delivery reliability (delivery of the right vehicle at the right time to customers) & 12 & 86.25 & 90.00 \\
\hline Cost (associated with producing the vehicle) & 12 & 85.00 & 87.50 \\
\hline Supplier reliability (we rely on the effectiveness of our suppliers) & 12 & 85.00 & 90.00 \\
\hline Order delivery lead time (time taken to complete all activities from order to delivery) & 12 & 79.58 & 80.00 \\
\hline Responsiveness (how quickly vehicles are delivered to customers) & 12 & 76.25 & 75.00 \\
\hline Flexibility (ability to respond to changing needs of customers) & 12 & 74.17 & 80.00 \\
\hline Supply chain asset management (effectiveness of managing assets to support demand satisfaction) & 12 & 72.08 & 77.50 \\
\hline Product variety (variety of models of the vehicle offered to the market) & 12 & 71.25 & 80.00 \\
\hline Innovation (radical and incremental changes in the vehicle production process) & 12 & 67.50 & 72.50 \\
\hline
\end{tabular}

Table 5 indicates that, overall, quality was considered the most important performance indicator (a mean of 90.83), followed by final product delivery reliability (a mean of 86.25) and then cost and supplier reliability (a mean of 85.00). Innovation and product variety were rated the lowest, which may be explained by the fact that most of the vehicle models made in South Africa are low-cost, standard vehicles. Hence, there is a limited variety of production models and little or no radical change in the production process. Respondents were also requested to indicate the reasons for their ratings. Table 6 summarises the responses. These are categorised into competition, quality, cost, export and lead time. 
Table 6: Key Reasons for Rating of Supply Chain Performance Indicators

\begin{tabular}{|l|l|}
\hline \multicolumn{1}{|c|}{ Category of Rating } & \multicolumn{1}{c|}{ Reasons } \\
\hline Competition & $\begin{array}{l}\text { "Based on the competitiveness of the industry, we benchmark our brand to exceed the } \\
\text { expectations of our competitors"; "We are in competition against Russian, Chinese and Indian } \\
\text { plants for new business ... they are very cost effective" }\end{array}$ \\
\hline Quality & $\begin{array}{l}\text { "We focus on quality vehicles to customers"; "Quality is an essential requirement, even if it costs } \\
\text { more"; "The mission of the group is to supply quality vehicles to customers"; "We do not } \\
\text { compromise quality for cost" }\end{array}$ \\
\hline Cost & $\begin{array}{l}\text { "Cost and on-time delivery are a key requirement"; "Low cost model, focus is on quality and } \\
\text { reliability"; "Cost is more important than the nice to have"; "Pay more attention to cost and } \\
\text { quality than others" }\end{array}$ \\
\hline Lead Time & $\begin{array}{l}\text { "Ensuring export deliveries on time while maintaining our profit margin"; "Lead time reduction } \\
\text { prioritised to increase free car flows" }\end{array}$ \\
\hline
\end{tabular}

Research Question 2: $\quad$ Are there any differences regarding the implementation of key supply chain performance indicators between manufacturers of different origin (parent) companies?

This question investigates responses on key performance indicators by the different vehicle manufacturers. Table 7 indicates mean values for supply chain performance indicators according to manufacturers. For the purpose of analysis, the following abbreviations were used: E1 for European manufacturer 1; E2 for European manufacturer 2; E3 for European manufacturer 3; AM for American manufacturer; A1 for Asian manufacturer 1; and A2 for Asian manufacturer 2.

Table 7: Key Supply Chain Performance Indicators by Manufacturers

\begin{tabular}{|l|c|c|c|c|c|c|}
\hline \multicolumn{1}{|c|}{ Supply Chain Indicators } & \multicolumn{5}{c|}{ Mean } \\
\cline { 2 - 7 } & E1 & AM & E2 & A1 & A2 & E3 \\
\hline Quality & 82.50 & 80.00 & 70.00 & 91.25 & 75.00 & 92.50 \\
\hline Final Product Delivery Reliability & 97.50 & 80.00 & 95.00 & 87.50 & 90.00 & 100.0 \\
\hline Cost & 95.00 & 42.50 & 80.0 & 78.75 & 50.00 & 85.00 \\
\hline Supplier Reliability & 87.50 & 72.50 & 95.00 & 91.25 & 60.00 & 90.00 \\
\hline Order Delivery Lead Time & 95.00 & 37.50 & 90.00 & 60.00 & 60.00 & 77.50 \\
\hline Responsiveness & 90.00 & 55.00 & 90.00 & 78.75 & 70.00 & 75.00 \\
\hline Flexibility & 90.00 & 62.50 & 90.00 & 85.00 & 75.00 & 72.50 \\
\hline Supply Chain Asset Management & 95.00 & 77.50 & 95.00 & 93.75 & 75.00 & 72.50 \\
\hline Product Variety & 95.00 & 37.50 & 80.00 & 72.50 & 60.00 & 80.00 \\
\hline Innovation & 87.50 & 50.00 & 80.00 & 77.50 & 40.00 & 80.00 \\
\hline
\end{tabular}
indicators:

As indicated in Table 6, the following discussions reflect the manufacturers' perspectives on supply chain

1) The most implemented indicator for European manufacturer 1 was final delivery reliability (a mean of 97.50) followed by cost, order delivery lead time and product variety (a mean of 95.00). The lowest rating was recorded for quality (a mean of 82.50), but since this value was still above 80, it clearly indicates that all of these indicators were considered important for optimising supply chain performance.

2) For the American manufacturer, quality and final delivery reliability were the most important indicators (a mean of 80.00), followed by supply chain asset management (a mean of 77.50). The least implemented indicators were order delivery lead time and product variety (a mean of 37.50), clearly indicating that the indicators were not that important in optimising supply chain performance.

3) The most implemented indicators for European manufacturer 2 were final product delivery reliability, supplier reliability and supply chain asset management (a mean of 95.00). The lowest mean value of 70.00 was recorded for quality, indicating that it was not critically important, but still fairly important for optimising supply chain performance. It is interesting to note that for both European manufacturers 1 and 2 , quality was rated as the lowest value, but it was still above 70 .

4) For Asian manufacturer 1, supply chain asset management was the most important indicator (a mean of 93.75), followed by quality and supplier reliability (means of 91.25). The least important indicator was order delivery lead time (a mean of 60.00). 
5) According to Asian manufacturer 2, final delivery reliability was the most important indicator (a mean of 90.00), followed by quality, flexibility and supply chain asset management (a mean of 75.00). The least implemented indicator was innovation (a mean of 40.00).

6) Final delivery reliability was the most important indicator for European manufacturer 3 (a mean of 100.0), followed by quality (a mean of 92.50). Flexibility and supply chain asset management were considered the least important (a mean of 72.50).

Quality was not as important an indicator for European manufacturers 1 and 2 as it was for the Asian manufacturers. European manufacturers 1 and 2 rated order delivery lead time, responsiveness and flexibility very high with a mean ranging from 90.00 to 95.00 , while these were not the most important indicators for Asian manufacturers. The highest rating for the indicators was final product reliability by European manufacturer 3 (a mean of 100.00), while order delivery lead time and product variety recorded the lowest rating by the American manufacturer (a mean of 37.50) indicating that it was of little importance. The results also show that all the indicators were very important for optimising supply chain performance for European manufacturers compared to the Asian and American manufacturers, indicating that European manufacturers exhibited some important characteristics of a responsive supply chain (that is, that they are agile).

In order to further determine the importance of the performance indicators of the different parent companies' origins in South Africa and their perception on the application of key performance indicators, the MannWhitney $\mathrm{U}$ test was conducted. The aim was to see whether there is a statistically significant difference between the parent company's continent of origin (Asia and Europe) with regard to their view on the importance of supply chain performance indicators in contributing to optimisation of the supply chain. The hypotheses testing for the importance of supply chain performance indicators were as follows:

$\mathbf{H}_{\mathbf{0}}$ : Local manufacturers of light vehicles of Asian and European origin do not differ statistically significantly with regard to their view on the importance of supply chain performance indicators.

$\mathbf{H}_{1}$ : Local manufacturers of light vehicles of Asian and European origin differ statistically significantly with regard to their view on the importance of supply chain performance indicators.

The Mann-Whitney U test conducted at 5\% level of significance revealed that local manufacturers of European and Asian origins agreed to a large extent on the importance of key performance indicators regarding supply chain, except for a few indicators. Table 8 reflects the statements in which there were statistically significant differences, at the $5 \%$ level of significance.

Table 8: Mann-Whitney Test: Significant Differences in Supply Chain Indicators

\begin{tabular}{|l|c|c|c|c|c|}
\hline \multicolumn{1}{|c|}{ Performance Indicators } & Mann-Whitney U & Wilcoxon W & $\mathbf{Z}$ & $\begin{array}{c}\text { Asymp sig } \\
(\mathbf{2} \text {-tailed) }\end{array}$ & $\begin{array}{c}\text { Exact sig } \\
{[2 *(\mathbf{1} \text {-tailed sig) }]}\end{array}$ \\
\hline Cost & 9.000 & 24.000 & -.745 & .456 & .548 \\
\hline Quality & 1.000 & 16.000 & -2.471 & .013 & .016 \\
\hline Flexibility & 6.000 & 21.000 & -1.392 & .164 & .222 \\
\hline Dependability/Reliability & 12.000 & 27.000 & -.108 & .914 & 1.000 \\
\hline Innovation & 2.000 & 17.000 & -2.207 & .027 & .032 \\
\hline Responsiveness & 8.000 & 23.000 & -.964 & .335 & .421 \\
\hline Order Delivery Lead Time & 11.000 & 26.000 & -.320 & .749 & .841 \\
\hline Delivery Reliability & 11.000 & 26.000 & -.325 & .745 & .841 \\
\hline Product Variety & 5.000 & 20.000 & -1.622 & .105 & .151 \\
\hline $\begin{array}{l}\text { Supply Chain Asset } \\
\text { Management }\end{array}$ & 6.500 & 21.500 & -1.273 & .203 & .222 \\
\hline
\end{tabular}

The alternative hypothesis was proven to be correct, as indicated below:

- $\quad$ Final product delivery reliability was statistically significantly more important in contributing to optimising supply chain performance in European manufacturers than in Asian manufacturers.

- Order delivery lead time was statistically significantly more important to optimising supply chain performance for European manufactures than Asian manufacturers. 
Table 9 presents a summary of Table 8, highlighting the few perceived differences in application of supply chain indicators, their mean rank and p-value.

Table 9: Significant Differences in Supply Chain Indicators

\begin{tabular}{|l|c|c|}
\hline Supply Chain Indicators & Mean Rank & p-value \\
\hline Final product delivery reliability (delivery of the right vehicle at the right time to customers) & $\begin{array}{c}\text { Asia }=3.20 \\
\text { Europe }=7.80\end{array}$ & .013 \\
\hline Order delivery lead time (time taken to complete all activities from order to delivery) & $\begin{array}{c}\text { Asia }=3.40 \\
\text { Europe }=7.60\end{array}$ & .027 \\
\hline
\end{tabular}

As indicated in Tables 7 and 8, final product delivery reliability and order delivery lead time tended to be more important in contributing to optimising supply chain performance for European manufacturers (mean rank of 7.80 and 7.60 respectively) compared to Asian manufacturers (mean rank of 3.20 and 3.40 respectively). This result attests to the fact that competitiveness in cost, quality and product offerings are critical issues for all manufacturers in the automotive industry.

\section{CONCLUSION}

The purpose of this article was to investigate key indicators used by light vehicle manufacturers in South Africa for optimising their supply chain performance. The article is exploratory and descriptive in nature and involved both qualitative and quantitative designs based on a survey. The target population was original equipment manufacturers (OEMs) in the South African automotive industry (all light vehicle manufacturers in South Africa). The research instrument was a semi-structured interview questionnaire. In this article, ten performance indicators were identified and the respondents were asked to rate, with a score between 0 and 100, how important the indicator's contribution is to the optimisation of supply chain performance. The results revealed that, overall, quality was considered the most important performance indicator, followed by final product delivery reliability and then cost and supplier reliability in optimising automotive industry supply chain performance. Innovation and product variety were rated the lowest.

With reference to the most important performance indicator by individual manufacturer, European manufacturers 1 and 2 indicated the highest ratings (means of 91.5 and 86.5) for all the performance indicators towards contributing to optimisation of supply chain performance. European manufacturers 1 and 2 also indicated the highest mean ratings for order delivery lead time, responsiveness and flexibility, indicating that they followed agile supply chain strategies. The lowest mean rating was recorded by the American manufacturer for order delivery lead time and product variety, which means that its focus was on a lean supply chain.

This result also shows that quality is not a negotiable issue in the automotive industry and is a key requirement for vehicle manufacturers. This is in line with other research findings. Automotive manufacturers are paying more attention to quality issues and thus reducing the number of defects in vehicles. Furthermore, there is no significant difference in quality between vehicles from Asia, America and Europe. The result further shows that all the indicators are essential for optimisation of supply chain performance for the European manufacturers compared to the Asian and American manufacturers, which indicates that the European manufacturers have a number of important characteristics of a responsive supply chain (such as agility).

\section{AUTHOR INFORMATION}

Intaher Marcus Ambe, University of South Africa (UNISA), Department of Business Management, South Africa. E-mail: Ambeim@unisa.ac.za

\section{REFERENCES}

1. Alfaro, A. L., Bizuneh, G., Moore, R., Ueno, S., \& Wang, R. (2012). South Africa: Automotive cluster, microeconomics of competitiveness. Harvard Business School: 1260, Kennedy School of Government: PED-329. 
2. $\quad$ Aramyan, L. H., Alfons G. J. M., Lansink, O., van der Vorst, J. G. A. J., \& van Kooten, O. (2007). Performance measurement in agri-food supply chains: A case study. Supply Chain Management: An International Journal, 12(4), 304-315.

3. Asadi, N. (2012). Performance indicators in internal logistic systems. 2012 International Conference on Innovation and Information Management (ICIIM 2012), IPCSIT: Vol. 36 (2012) IACSIT Press, Singapore, 48-52.

4. $\quad$ Basu, R. (2001). New criteria of performance measurement. Meas. Bus. Excel, 5(4), 7-12.

5. Bolstorff, P., \& Rosenbaum, R. (2003). Supply chain excellence: a handbook for dramatic improvement using the SCOR model. New York: Amacom.

6. Bora, A., Chiamsiri, S., \& Krairit, D. (2004). Developing key performance indicators for performance controlling of a supply chain. Proceedings of the Fifth Asia Pacific Industrial Engineering and Management Systems Conference 2004.

7. Bowersox, D. J., Closs, D.J., \& Cooper, MB. (2010). Supply chain logistics management. (3 ${ }^{\text {rd }}$ edition). Singapore: McGraw-Hill.

8. Bozarth, C. C., \& Handfield, R. B. (2006). Introduction to operations and supply chain management. Upper Saddle River, NJ: Pearson Prentice Hall.

9. Burt, D. N., Petcavage, S. D., \& Pinkerton, R. L. (2010). Supply management. Boston: McGraw-Hill Irwin.

10. Cai, J., Liu, X., Xiao, Z., \& Liu, J. (2009). Improving supply chain performance management: A systematic approach to analyzing iterative KPI accomplishment. Decision Support Systems, 46(2009), 512-521.

11. Chae, B. (2009). Developing key performance indicators for supply chains: an industry perspective. Supply Chain Management: An International Journal, 14(6), 422-428.

12. Cohen, S., \& Rousell, J. (2005). Strategic supply chain management: the five disciplines for top performance. New York: McGraw-Hill.

13. Fawcett, S. E., Ellram, L. M., \& Ogden, J. A. (2007). Supply chain management: from vision to implementation. Upper Saddle River, NJ: Prentice Hall.

14. Fitzgerald, L., Johnston, R., Brignall, S., Silvestro, R., \& Voss, C. (1991). Performance measurement in service business. CIMA: London.

15. Folan, P., \& Browne, J. (2005). A review of performance measurement: Towards performance management. Comp. Indus., 56, 663-680.

16. Godlevskaja, O., Van Iwaarden, J., \& Van der Wiele, T. (2011). Moving from product-based to servicebased business strategies: Services categorisation schemes for the automotive industry. International Journal of Quality and Reliability Management, 28(1), 62-94.

17. Gunasekaran, A., \& Kobu, B. (2007). Performance measures and metrics in logistics and supply chain management: A review of recent literature (1995-2004) for research and applications. International Journal of Production Research, 45(12), 2819-2840.

18. Handfield, R. B., Monczka, R. M., Giuinipero, L. C., \& Patterson, J. L. (2011). Sourcing and supply chain management ( $5^{\text {th }}$ edition). Toronto: Southern Western.

19. Hugo, W. M. J., Badenhorst-Weiss, J. A., \& Van Biljon, E. B. H. (2004). Supply chain management: logistics in perspective ( $3^{\text {rd }}$ edition). Pretoria: Van Schaik.

20. Jacobs, F. R., Chase, R. B., \& Aquilano, N. J. (2009). Operations and supply management (12 $2^{\text {th }}$ ed.). New York, McGraw-Hill.

21. Jonsson, P. (2008). Logistics and supply chain management. London: McGraw-Hill.

22. Lambert, D. M., \& Pohlen T. L. (2001). Supply Chain Metrics. The International Journal of Logistic Management, 12(1), 1-19.

23. Lambert, D.L. (2006). Supply chain management: processes, partnerships, performance ( $2^{\text {nd }}$ edition). Florida, Hartley Press.

24. McDaniel, C., \& Gates, R. (2001). Marketing research essentials. Cincinnati, OH: South-Western College.

25. Neto, M. S., \& Pires, S. R. I. (2011). Performance measurement in supply chains: A study in the automotive industry, in supply chain management. Chapter 15, 331-350, InTech, Croatia, 2011.

26. Petterson, J. (2009). Defining lean production: some conceptual and practical issues. TQM Journal, 21(2), 127-142.

27. Sezen, B. (2008). Relative effects of design, integration and information sharing on supply chain performance. Supply Chain Management: An International Journal, 13(3), 233-240. 
28. Stavrulaki, E., \& Davis, M. (2010). Aligning products with supply chain processes and strategy. The International Journal of Logistics Management, 21(1), 127-151.

29. Stewart, G. (1995). Supply chain performance benchmarking study reveals keys to supply chain excellence. Logistics Information Management, 8, 38-44.

30. Taylor, D. A. (2004). Supply chains: a manager's guide. Boston: Addison-Wesley.

31. The Supply-Chain Council. (2008). Scor 9.0 Booklet. The Supply-Chain Council, [Online] Retrieved Nov. 2008, from www.supply-chain.org

32. Van der Vorst, J. G. A. J. (2000). Effective food supply chains. Generating, modelling and evaluating supply chain scenarios. (PhD thesis). Wageningen University, Wageningen.

33. van Landeghem, R., \& Persoons, K. (2001). Benchmarking of logistical operations based on a causal model. International Journal of Operation and Prodution Management, 21, 254-266.

34. Wang, W. Y. C., Heng, M. S. H., \& Chau, P. Y. K. (2007). Supply chain management: issues in the new era of collaboration and competition. London: Idea group.

35. Wong W. P., \& Wong K. Y. (2008). A review on benchmarking of supply chain performance measures. Benchmarking: An International Journal, 15(1), 25-51.

36. Wisner, J. D, Tan, K-C., \& Leong, G. K. (2008). Principles of supply chain management: a balanced approach. Mason, OH: South-Western Cengage Learning.

37. Wisner, J. D, Tan, K-C., \& Leong, G. K. (2012). Principles of supply chain management: a balanced approach ( $3^{\text {rd }}$ edition). Mason, Ohio: South-Western Cengage Learning.

38. Zikmund, W. G., Babin, B. J., Carr, J. C., \& Griffin, M. (2010). Business research methods. Ohio: SouthWestern Cengage Learning. 
NOTES 